\title{
Characterization of Big Dynorphins from Rat Brain and Spinal Cord
}

\author{
Guo-Xi Xie and Avram Goldstein \\ Addiction Research Foundation and Stanford University, Palo Alto, California 94304
}

To examine the processing of products of the dynorphin gene in the central nervous system, immunoreactive (ir) $\mathrm{dy}$ norphin (Dyn) A, Dyn B, Dyn A-(1-8), $\alpha$ - and $\beta$-neo-endorphin ( $\alpha$ - and $\beta$-Neo) in rat brain and spinal cord were measured, using specific antisera after gel filtration and high-performance liquid chromatography (HPLC). Three peaks of $\mathbf{M}_{\text {r }}$ about 8, 4, and 2 kDa for ir-Dyn $A$ and ir-Dyn $B$, and one peak of $M$ less than 2 kDa for ir-Dyn $A-(1-8)$, ir- $\alpha-$, and ir- $\beta$-Neo were found both in the brain and in the spinal cord. The 8 kDa peak was recognized by Dyn $A$ and Dyn $B$ antisera and, after hydrolysis by proline-specific endopeptidase, by $\beta$-Neo antiserum. The $8 \mathrm{kDa}$ peak was recognized by a monoclonal antibody against the amino terminal sequence Tyr-Gly-GlyPhe of all opioid peptides and by an antiserum directed toward the carboxyl terminus of Dyn $B$, indicating that it contains, from the amino terminal tyrosine of neo-endorphin to the carboxyl-terminal threonine of Dyn B, all 3 opioid peptide regions in the prodynorphin. By means of proline-specific endopeptidase hydrolysis, we also found a big dynorphin precursor $\left(M_{r} \simeq 26 \mathrm{kDa}\right)$ in both brain and spinal cord.

Since the discovery of dynorphin (Dyn) A in 1979 (Goldstein et al., 1979), other opioid peptides belonging to the same family Dyn B (Fischli et al., 1982; Kilpatrick et al., 1982), Dyn-32 (Fischli et al., 1982), Dyn A-(1-8) (Minamino et al., 1980), $\alpha$-Neo (Kangawa et al., 1981), $\beta$-Neo (Minamino et al., 1981), and leumorphin (Nakao et al., 1983) - have been isolated from mammalian neural tissues (Fig. 1). Although the amino acid sequence of their common precursor preprodynorphin from porcine, rat, and human was deduced using the cDNA hybridization technique (Kakidani et al., 1982; Horikawa et al., 1983; Civelli et al., 1985), very little was known about the processing and posttranslational regulation of the dynorphin gene products in different tissues. In the case of the other 2 opioid peptide families, prcproopiomclanocortin (POMC) and preproenkephalin, however, processing has been analyzed in detail in pituitary (reviewed by Civelli et al., 1984) and adrenal medulla (Udenfriend and Kilpatrick, 1984), respectively. It was shown that for POMC and preproenkephalin there were different modes of processing in different tissues. Cone et al. (1983) reported that there were $\mathrm{M}_{r}$ about 7,4 , and $2 \mathrm{kDa}$ immunoreactive (ir)-Dyn

Received Sept. 23, 1986; revised Dec. 11, 1986; accepted Jan. 14, 1987.

This investigation was supported by Grants BNS-84-16617 from the National Science Foundation and DA-1199 from the National Institute on Drug Abuse. We are grateful to Dr. F. Weber (The Oregon Health Sciences University) for his gift of $\alpha$ - and $\beta$-Neo antisera, and to Dr. A. Herz (Max-Planck-Institute for Psychiatry, FRG) for his gift of monoclonal antibody $3 E 7$.

Correspondence should be addressed to Dr. Avram Goldstein, Addiction Research Foundation, 701 Welch Road, Suite 325, Palo Alto, CA 94304.

Copyright (C) 1987 Society for Neuroscience $0270-6474 / 87 / 072049-07 \$ 02.00 / 0$ in rat brain. A similar result was observed by Seizinger et al. (1984). High-performance liquid chromatography (HPLC) coelution (Conc et al., 1983) and amino acid sequence analysis (Fischli et al., 1982) showed that $4 \mathrm{kDa}$ Dyn was Dyn-32, which is Dyn A and Dyn B linked by Lys-Arg. But little has been known about the "7 $\mathrm{kDa}$ " product. We report here the partial purification and characterization of this material from rat brain and spinal cord. Using several specific antisera and a monoclonal antibody, as well as proline-specific endopeptidase (PSE) hydrolysis, we demonstrated that it contains neo-endorphin (Neo), Dyn A, and Dyn B. In the same way we found a $26 \mathrm{kDa}$ Dyn precursor in rat brain and spinal cord.

\section{Materials and Methods}

Peptides, antibodies and radioimmunoassays. Except as noted, all peptides were from Peninsula Laboratories (Belmont, CA). Purity was verified by reverse-phase HPI $C$ analysis ( $\mu$ Bondapak $C_{18}$ column).

The specificities of antisera against Dyn A ("Lucia"; Ghazarossian et al., 1980; Cone et al., 1983) and Dyn B ("13S" and "17S"; Cone and Goldstein, 1982; Devi and Goldstein, 1984) from our laboratory, against Dyn A-(1-8) (Weber et al., 1982a) and $\alpha$ - and $\beta$-Neo (Weber et al., $1982 \mathrm{~b}$ ) from Dr. E. Weber, and of the monoclonal antibody (3E7) specific to amino-terminal Tyr-Gly-Gly-Phe of opioid peptides (Meo et al., 1983) from Dr. A. Herz have been described elsewhere and are summarized in Table 1.

Radioimmunoassays (RIAs) for Dyn A, Dyn B, Dyn A-(1-8), $\alpha$ - and $\beta-\mathrm{Neo}$ were carried out under the same conditions. Iodination of each peptide was performed using the chloramine-T method. ${ }^{125}$ I-labeled tracers for each RIA were purified first by Sep-Pak $C_{18}$ cartridges, and then by reverse-phase HPLC. Synthetic peptide standards were prepared in acidified methanol (MeOH:0.1 M HCl, 1:1, vol/vol). Antibody dilution was chosen for $30 \%$ binding of counts added. Phosphate buffer $(0.15 \mathrm{M})$, with $0.1 \% \mathrm{BSA}$ and $0.1 \%$ Triton $\mathrm{X}-100(\mathrm{pH} 7.4)$, was used in the RI $\Lambda$. Total volume in each tube was $300 \mu \mathrm{l}$. A charcoal suspension (charcoal, $5 \mathrm{gm}$; dextran, $0.3 \mathrm{gm}$; horse serum, $12 \mathrm{ml} ; 0.15 \mathrm{~m}$ phosphate buffer, $88 \mathrm{ml}$ ) was added in a volume of $1.2 \mu \mathrm{l}$ to separate free and bound tracer. After centrifugation, the radioactivity of the supernatant was determined. All steps were performed below $4^{\circ} \mathrm{C}$.

Since the monoclonal antibody $3 \mathrm{E} 7$ recognizes the amino-terminal tyrosine of opioid peptides, the conventional iodination method is not suitable for this RIA. Therefore, the iodination of $\beta$-Neo was carried out with its amino terminus protected by the monoclonal antibody, as follows: $\beta$-Neo $(1 \mathrm{nmol})$, with $200 \mu \mathrm{g}$ of protein A-Sepharose CL-4Bpurified monoclonal antibody $3 \mathrm{E} 7$, was first incubated at $4^{\circ} \mathrm{C}$ for $24 \mathrm{hr}$. The peptide-antibody complex was then iodinated, applied to a Sephadex G-25 column $(0.8 \times 18 \mathrm{~cm})$, and eluted with $0.15 \mathrm{~m}$ phosphate buffer ( $\mathrm{pH} 7.4)$. The fraction $(1 \mathrm{ml})$ containing the first peak of radioactivity was collected. The complex was dissociated by adding $200 \mu \mathrm{l}$ of glacial acetic acid and then the labeled $\beta$-Neo was separated from antibody by reverse-phase HPLC.

The sensitivities of all seven RIAs were determined to be 10-100 fmol/tube $\left(\mathrm{IC}_{50}\right.$ values, the concentrations of nonradioactive peptide required to reduce tracer binding by $50 \%$ ).

Tissue extraction. Male Sprague-Dawley rats (300-350 gm) were killed by decapitation. The brain was removed immediately, frozen on dry ice, and weighed. In order to quickly remove the whole spinal cord, the vertebral column was transected at the last lumbar vertebra, and the end of a blunt \#16 needle was inserted into the lumbar vertebral canal. 


$$
\begin{array}{ll}
\text { a-Neo } & \text { Tyr-Gly-Gly-Phe-Leu-Arg-Lys-Tyr-Pro-Lys } \\
\text { B-Neo } & \text { Tyr-Gly-Gly-Phe-Leu-Arg-Lys-Tyr-Pro } \\
\text { Dyn A } & \text { Tyr-Gly-Gly-Phe-Leu-Arg-Arg-Ile-Arg-Pro-Lys-Leu-Lys-Trp-Asp-Asn-Gin } \\
\text { Dyn A-8 } & \text { Tyr-Gly-Gly-Phe-Leu-Arg-Arg-Ile } \\
\text { Dyn B } & \text { Tyr-Gly-Gly-Phe-Leu-Arg-Arg-Gln-Phe-Lys-Val-Val-Thr } \\
\text { Leu-Enk } & \text { Tyr-Gly-Gly-Phe-Leu }
\end{array}
$$

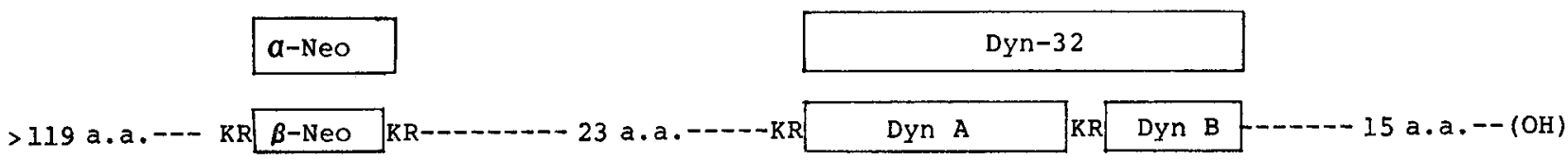

Figure 1. Opioid peptides contained in the deduced rat prodynorphin sequence (Civelli et al., 1985). The $\mathrm{NH}_{2}$-terminal sequence was not reported in full. $K R$ indicates Lys-Arg cleavage sites.

By means of a $30 \mathrm{ml}$ syringc, a few millilitcrs of cold saline solution were forced into the vertebral canal, extruding the whole intact spinal cord (torn from its roots) from the cervical cut end onto a chilled plate. After carefully removing the meninges, the cord was frozen on dry ice and weighed.

Each brain and spinal cord was separately homogenized (Tekmar Tissumizer) in 10 volumes (vol/wt) of $0.1 \mathrm{~m}$ acetic acid at $100^{\circ} \mathrm{C}$ and incubated at the same temperature for $30 \mathrm{~min}$. The homogenate was centrifuged $\left(20,000 \times g ; 4^{\circ} \mathrm{C}, 30 \mathrm{~min}\right)$ and the supernatant was lyophilized.

Gel chromatography, cation exchange, Sep-Pak $C_{18}$ cartridge, and $H P L C$. Each extract, representing a single brain or spinal cord, was redissolved in $2 \mathrm{ml}$ of $0.15 \mathrm{M}$ acetic acid containing $0.1 \%$ Triton $\mathrm{X}-100$ and $0.15 \mathrm{M} \mathrm{NaCl}$ and centrifuged again $\left(20,000 \times g ; 4^{\circ} \mathrm{C}, 10 \mathrm{~min}\right)$. The supcrnatant was applied to a Sephadex G-50 column $(1.5 \times 90 \mathrm{~cm}$; Pharmacia) pre-equilibrated with $0.15 \mathrm{M}$ acetic acid containing Triton $\mathrm{X}-100$ and $\mathrm{NaCl}$ and eluted with the same solvent at a flow rate of 20 $\mathrm{ml} / \mathrm{hr}$ at $4^{\circ} \mathrm{C}$. Fractions $(2 \mathrm{ml})$ were collected, lyophilized, and redissolved in $600 \mu \mathrm{l}$ of $0.15 \mathrm{M}$ phosphate buffer for RIA.

Fractions containing the same peak $\left(\mathrm{M}_{\mathrm{r}} \simeq 8 \mathrm{kDa}\right)$ of ir-Dyn were pooled and applied to a CM-Sephadex C-25 column $(0.8 \times 18 \mathrm{~cm})$ preequilibrated with $0.1 \mathrm{M}$ acetic acid. The column was eluted with a linear gradient of $0-0.8 \mathrm{M} \mathrm{NaCl}$ in $0.1 \mathrm{M}$ acetic acid.

Fractions containing Dyn immunoreactivities were pooled again and applied to Sep-Pak $\mathrm{C}_{18}$ cartridges and HPLC for further purification. Sep-Pak $C_{18}$ was first purged by methanol and equilibrated with $5 \mathrm{~mm}$ trifluoroacetic acid (TFA). After applying the sample, which represented a single brain or spinal cord, the cartridge was washed with $5 \mathrm{ml}$ of 5
mM TFA in $\mathrm{H}_{2} \mathrm{O}, 20 \% \mathrm{CH}_{3} \mathrm{CN}$, and $50 \% \mathrm{CH}_{3} \mathrm{CN}$ sequentially. The 3 fractions were lyophilized for HPLC analysis. After being redissolved (100 $\mu \mathrm{l}$ of $5 \mathrm{~mm}$ TFA), each sample was injected onto a reverse-phase HPLC $\mu$ Bondapak $\mathrm{C}_{18}$ column $(3.9 \mathrm{~mm} \times 30 \mathrm{~cm})$ and eluted with a linear gradient of $20-50 \% \mathrm{CH}_{3} \mathrm{CN}$ in $5 \mathrm{~mm}$ TFA (flow rate, $1.5 \mathrm{ml} / \mathrm{min}$; $30 \mathrm{~min})$. Fractions $(0.6 \mathrm{ml})$ were lyophilized for RIA.

To determine more accurately the molecular weight of big dynorphins, a gel filtration HPLC column $(300 \times 7.5 \mathrm{~mm}$; Bio-Sil TSK 400 , BioRad, Richmond, CA) was pre-equilibrated and eluted with $0.15 \mathrm{~m}$ phosphate buffer ( $\mathrm{pH}$ 7.4). Samples from Sephadex G-50 fractions were lyophilized and redissolved in phosphate buffer, and $100 \mu \mathrm{l}$ was applied. Fractions $(0.6 \mathrm{ml})$ were assayed by RIA.

Proline-specific endopeptidase treatment. In order to determine whether the larger-molecular-weight forms of ir-Dyn contained the Neo sequence, PSE (Seikagaku Kogyo Co., Tokyo) was employed to hydrolyze the sample. This enzyme, isolated and purified from Flavobacterium sp. by Yoshimoto et al. (1980), cleaves specifically the peptide bonds on the carboxyl side of proline residues. PSE was dissolved in $0.15 \mathrm{M}$ phosphate buffer ( $\mathrm{pH} 7.4)$ to different concentrations $(6.25-400 \mathrm{mU} /$ $100 \mu 1)$. PSE solutions $(100 \mu 1)$ were added to sample tubes and incubated for different periods $(0-320 \mathrm{~min})$ at $37^{\circ} \mathrm{C}$. The reaction was terminated by boiling for $15 \mathrm{~min}$. Immunoreactive- $\beta$-Neo was measured by RIA using the specific antiserum to the carboxyl terminus of $\beta$-Neo.

Because the PSE may contain traces of trypsin and aminopeptidase contaminants, different enzyme inhibitors were tested: $3.3 \times 10^{-5} \mathrm{M}$ of soybean trypsin inhibitor, aprotinin, leupeptin, bestatin, thiorphan, captopril, phenylmethylsulfonyl fluoride (PMSF), L-Leu-L-Leu, poly-Arg, and $3.3 \times 10^{-6} \mathrm{M}$ of Dyn A-(1-8). Captopril was purchased from Squibb

Table 1. Specificities of antibodies in RIA

\begin{tabular}{lccccccc}
\multicolumn{7}{c}{ Cross-reactivity of antibody (\%) } \\
\cline { 2 - 7 } Peptide & $\begin{array}{l}\text { Dyn A } \\
\text { (Lucia) }\end{array}$ & $\begin{array}{l}\text { Dyn B } \\
(13 S)\end{array}$ & $\begin{array}{l}\text { Dyn B } \\
(17 S)\end{array}$ & $\begin{array}{l}\text { Dyn } \\
\text { A-(1-8) }\end{array}$ & $\alpha$-Neo & $\beta$-Neo & 3 E7 \\
\hline Dyn A & 100 & $5 \times 10^{-5}$ & 0 & 0 & 7 & 0 & - \\
Dyn A-(1-13) & 100 & $5 \times 10^{-5}$ & 0 & 0 & 0 & 0 & 16 \\
Dyn A-(1-8) & 0.25 & 0 & 0 & 100 & 0 & 0 & - \\
Dyn-32 & 36 & 89 & 37 & 0 & 0 & 0 & - \\
Dyn B & 0 & 100 & 100 & 0 & 0 & 0 & - \\
Leumorphin & 0 & 20 & 0 & 0 & 0 & 0 & - \\
[Leu]Enk & $<10^{-6}$ & 0 & 0 & 0 & 0 & 0 & 80 \\
[Met]Enk & $<0.001$ & 0 & 0 & 0 & 0 & 0 & 80 \\
$\alpha$-Neo & $<0.036$ & 0 & 0 & 0 & 100 & $<0.01$ & 20 \\
$\beta$-Neo & $<0.01$ & 0 & 0 & 0 & $<0.01$ & 100 & 20 \\
$\beta$-Endorphin & $<0.001$ & 0 & 0 & 0 & 0 & 0 & 100
\end{tabular}

Cross-reactivities are based on $\mathrm{IC}_{50}$ values, as reported by the respective authors (see Materials and Methods). Dash, no data reported. Enk, enkephalin. 

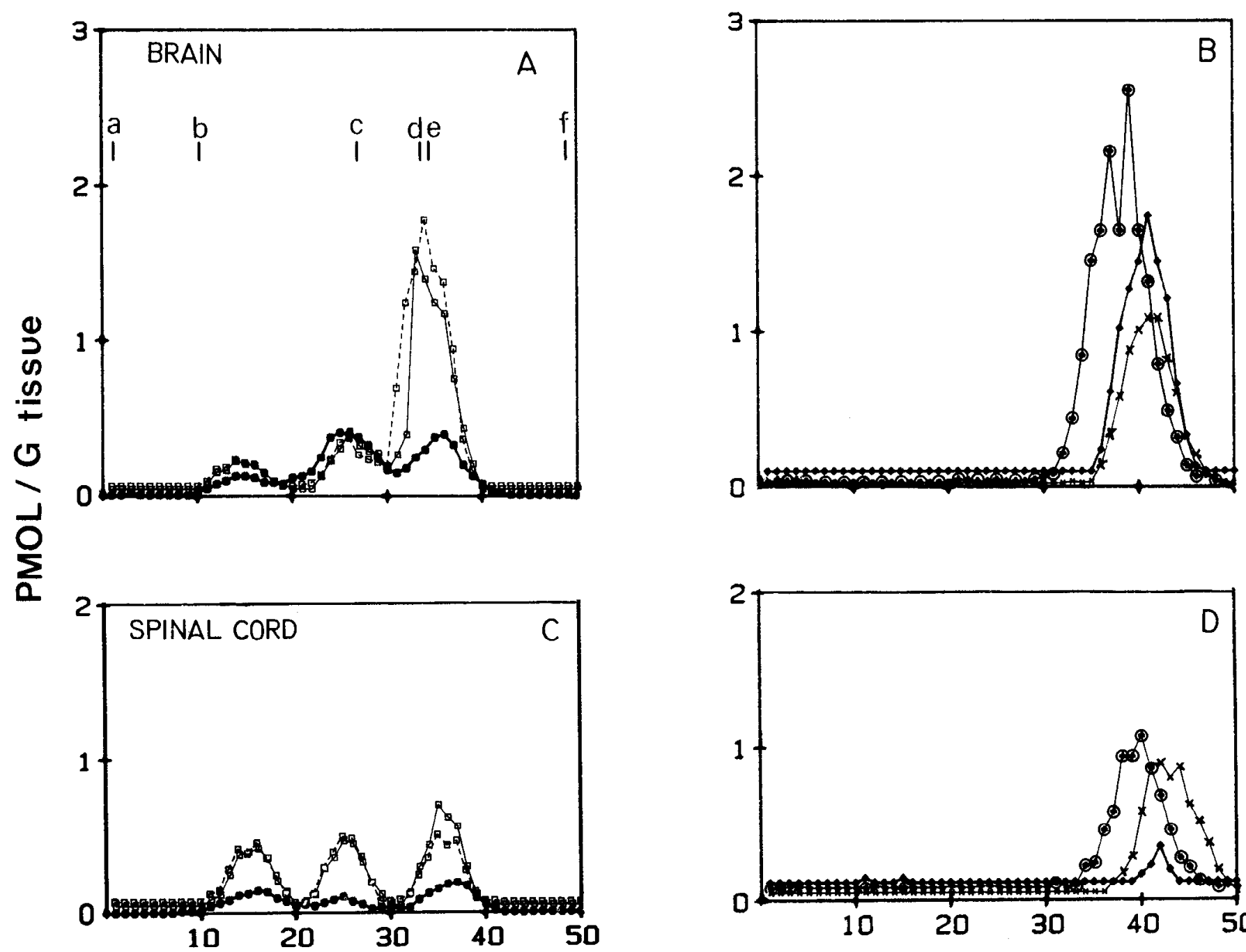

\section{FRACTION NO.}

$$
\begin{aligned}
& \rightarrow \text { ir-dynA (Lucia) } \\
& \square \text { ir-dyn B (13S ) } \\
& \square \text { ir-dyn B (17S) }
\end{aligned}
$$

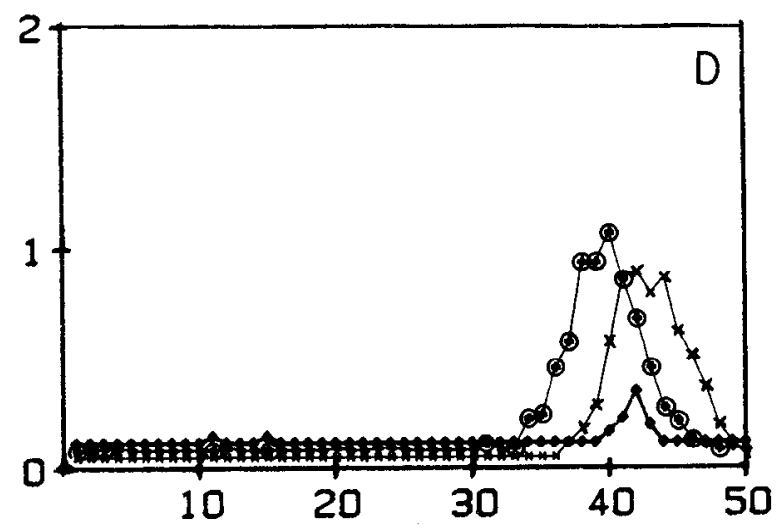

Figure 2. Sephadex G-50 chromatography of rat brain and spinal cord extracts. Data are picomoles of ir-peptide/gm tissue (wet weight). Fractions from the same rat brain $(A, B)$ and spinal cord $(C, D)$ were assayed for Dyn A, Dyn B, Dyn A- $(1-8), \alpha$-Neo, and $\beta$-Neo (see symbols). Inhibition of tracer binding by $15 \%$ was taken to be the detection limit in RIA. Molecular-weight calibration standards: $a$, Blue dextran $\left(\mathrm{M}_{r}=2\right.$ million); $b$, cytochrome c $\left(\mathrm{M}_{r}=13,000\right) ; c$, Dyn-32 $\left(\mathrm{M}_{r}=3985\right) ; d,{ }^{125} \mathrm{I}$-Dyn A $\left(\mathrm{M}_{r}=2272\right) ; \boldsymbol{e},{ }^{125} \mathrm{I}-\mathrm{Dyn} \mathrm{B}\left(\mathrm{M}_{r}=1695\right) ; f, \mathrm{CoCl}_{2}\left(\mathrm{M}_{r}=238\right)$.

(Princeton, NJ), aprotinin from CalBiochem-Behring Corp. (La Jolla, $\mathrm{CA}$ ), and the other inhibitors from Sigma (St. Louis, MO). The aminopeptidase $\mathrm{M}$ used in this study was purchased from Boehringer Mannheim Biochemicals (Indianapolis, IN).

\section{Results}

Gel chromatography of rat brain and spinal cord extracts Sephadex G-50 gel filtration of a single rat brain extract showed 3 peaks of $\mathrm{M}_{r}$ about 8, 4, and $2 \mathrm{kDa}$ for ir-Dyn A and Dyn B, and one peak $\left(\mathrm{M}_{r}\right.$ less than $\left.2 \mathrm{kDa}\right)$ each for ir-Dyn A-(1-8) and $\alpha$ - and $\beta$-Neo (Fig. $2, A, B$ ). Similar profiles were observed in the spinal cord extract from the same rat (Fig. 2,C,D). Five other rats (not shown) gave qualitatively and quantitatively similar peaks. It is noteworthy that both $13 \mathrm{~S}$ (which recognizes the midportion and carboxyl terminus of Dyn B) and 17S (which is specific to the free carboxyl terminus of Dyn B) detected about the same amount of ir-Dyn B in all 3 peaks from both brain and spinal cord, suggesting that the 3 sizes of ir-Dyn B end at the carboxyl-terminal threonine-13. The amount of smaller $\mathbf{M}_{r}$ (less than $2 \mathrm{kDa}$ ) ir-Dyn as compared to larger forms was much more abundant in the brain than in the spinal cord.

\section{Hydrolysis by proline-specific endopeptidase}

The intact $8 \mathrm{kDa}$ ir-Dyn from brain and spinal cord was not recognized by the $\beta$-Neo carboxyl-terminally directed antiserum. The carboxyl-terminal amino acid of $\beta-\mathrm{Neo}$ is proline. If a precursor peptide contains $\mathrm{Neo}$, it should generate $\beta$-Neo 
Figure 3. Hydrolysis of $8 \mathrm{kDa}$ ir-Dyn from rat brain by different concentrations of PSE. Incubation was at $37^{\circ} \mathrm{C}$ for $2 \mathrm{hr}$.

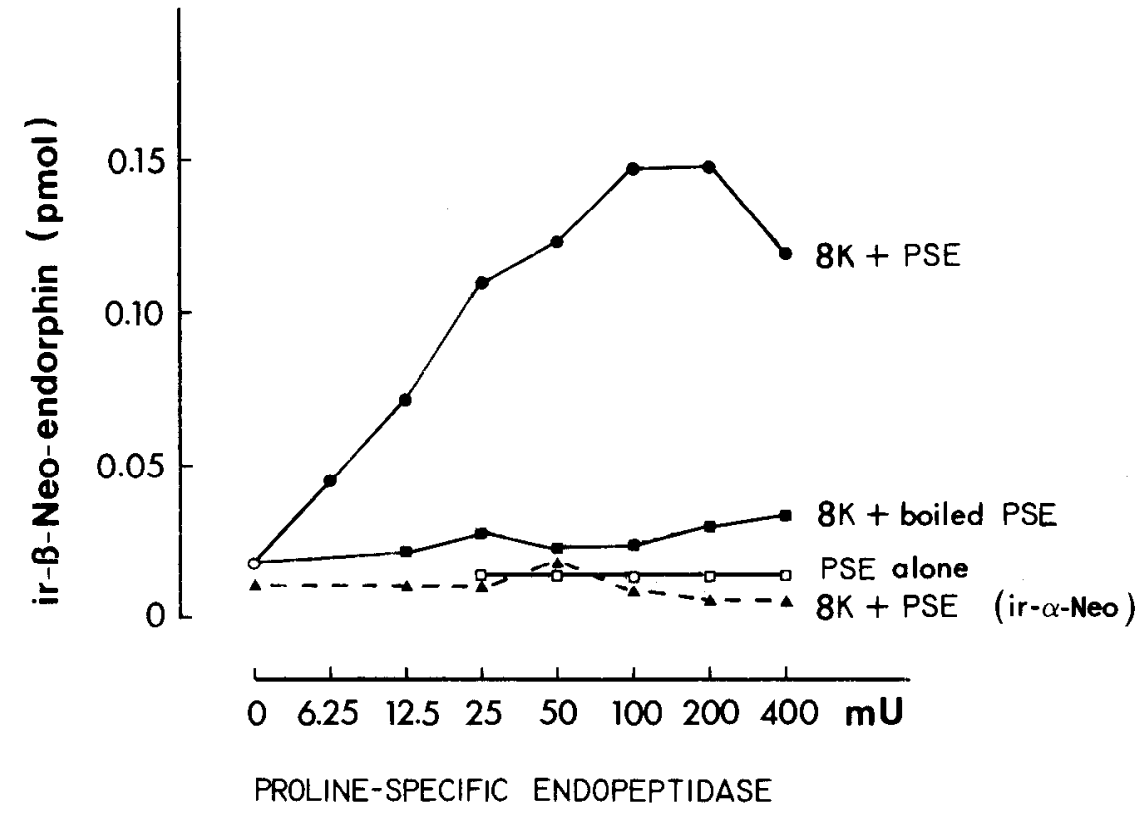

immunoreactivity (but not $\alpha$-Neo immunoreactivity) after hydrolysis by PSE. When incubated with different concentrations of PSE for $2 \mathrm{hr}$ at $37^{\circ} \mathrm{C}, 8 \mathrm{kDa}$ Dyn from brain generated different amounts of ir- $\beta$-Neo (Fig. 3) as the enzyme increased from 0 to $100 \mathrm{mU}$, but higher PSE resulted in lower levels of $\beta$-Neo. Similar results were obtained with spinal cord. Neither PSE incubated alone nor $8 \mathrm{kDA}$ Dyn incubated with boiled PSE generated ir- $\beta$-Neo, and $8 \mathrm{kDa}$ ir-Dyn incubated with PSE did not produce ir- $\alpha$-Neo.

When incubated with $100 \mathrm{mU}$ of PSE for different periods, $8 \mathrm{kDa}$ material produced measurable $\beta$-Neo after $2.5 \mathrm{~min}$ and reached a plateau after $80 \mathrm{~min}$; the level decreased gradually thereafter (Fig. 4). These results demonstrate that PSE did cleave Pro-Lys bonds of $8 \mathrm{kDa}$ Dyn to generate $\beta$-Neo immunoreactivity, but also that the enzyme preparation can destroy ir- $\beta$ Neo. Of the several enzyme inhibitors tested, only poly-Arg or PMSF could prevent the degradation. Incubation with PSE and PMSF or poly-Arg produced 2-fold more ir- $\beta$-Neo than did incubation without inhibitors, and the immunoreactivity level stayed at the plateau after longer incubation times (Fig. 4) and also at higher enzyme concentrations (data not shown).

\section{Ion-exchange, Sep-Pak $C_{18}$ and HPLC purification of $8 \mathrm{kDa}$ ir-Dyn}

Fractions containing $8 \mathrm{kDa}$ ir-Dyn peaks from Sephadex G-50 filtration of rat brain and spinal cord extracts were diluted with $0.1 \mathrm{M}$ acetic acid and applied to a CM-Sephadex cation exchanger. One main peak of ir-Dyn, eluted at about $0.4 \mathrm{M} \mathrm{NaCl}$, was pooled and added to Sep-Pak $\mathrm{C}_{18}$ cartridges. The eluates at 0 and $20 \% \mathrm{CH}_{3} \mathrm{CN}$ contained ir-Dyn A or B with $\mathrm{M}_{r}<5000$ when they were re-eluted from Sephadex G-50, and also they did not generate ir- $\beta$-Neo after PSE treatment. The eluate at $50 \% \mathrm{CH}_{3} \mathrm{CN}$ from Sep-Pak was further purified on HPLC to obtain a single peak recognized by Dyn A antiserum (Lucia), Dyn B antiserum (17S) and (after hydrolysis by PSE) $\beta$-Neo antiserum. This peak had a longer retention time on the $\mathrm{C}_{18}$
Figure 4. Time course of hydrolysis of $8 \mathrm{kDa}$ ir-Dyn by PSE and the effect of enzyme inhibitors. The temperature of incubation was $37^{\circ} \mathrm{C}$. PSE $(100 \mathrm{mU}$ in $100 \mu \mathrm{l}$ phosphate buffer) was added to each incubation tube. The final concentration of poly-Arg or PMSF in the incubation tube was $3.3 \times 10^{-5} \mathrm{M}$.

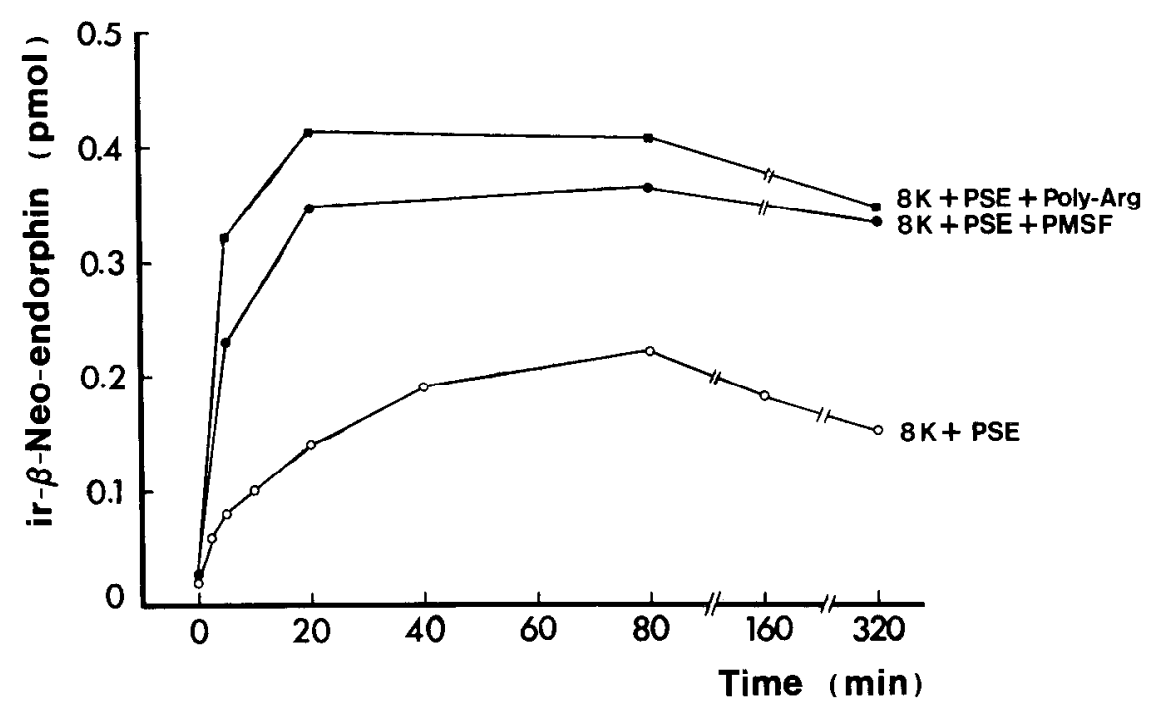




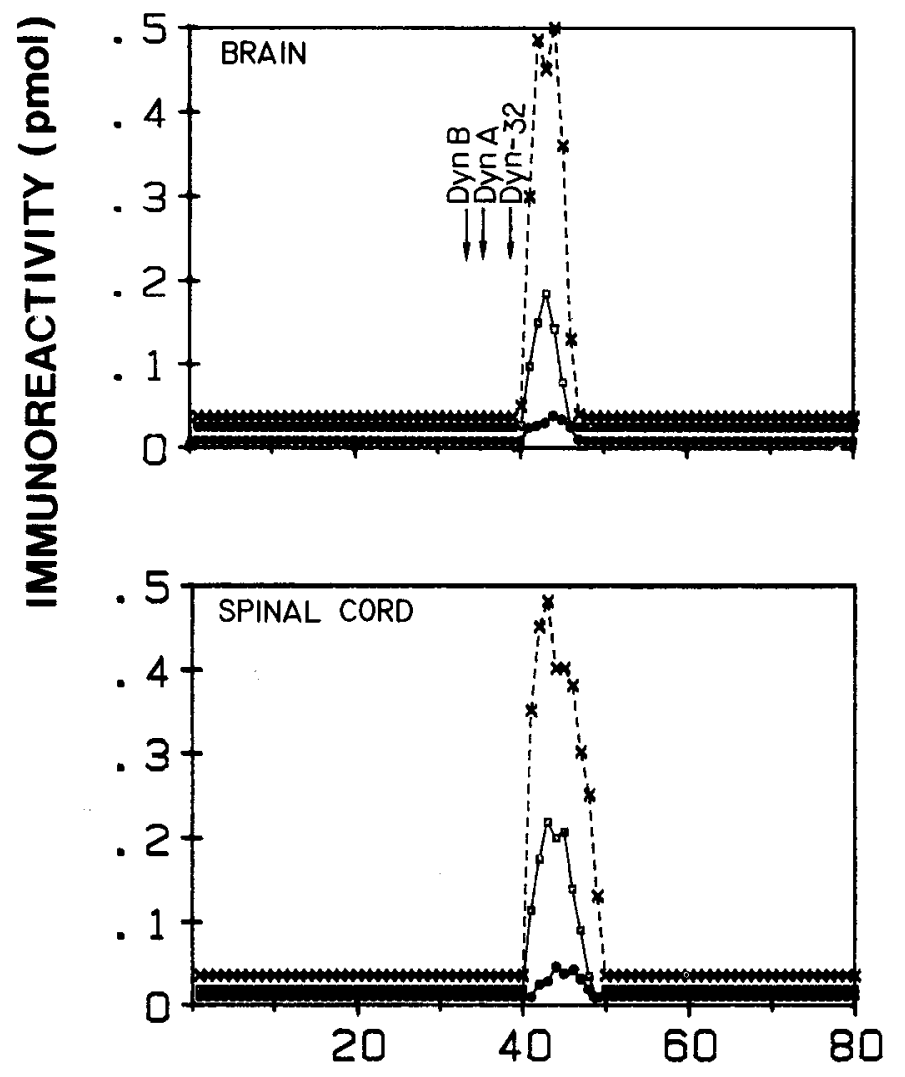

FRACTION No.

Figure 5. Reverse-phase HPLC purification of $8 \mathrm{kDa}$ Dyn. Top, Brain; bottom, spinal cord. Fractions $(0.6 \mathrm{ml})$ were assayed by Lucia $(\longrightarrow), 17 \mathrm{~S}(\square-\square)$, and (after PSE treatment) $\beta$-Neo antiserum $(x--x)$. Retention time calibration standards were run separately with 8 kDa Dyn.

RIA using monoclonal antibody $3 E 7$

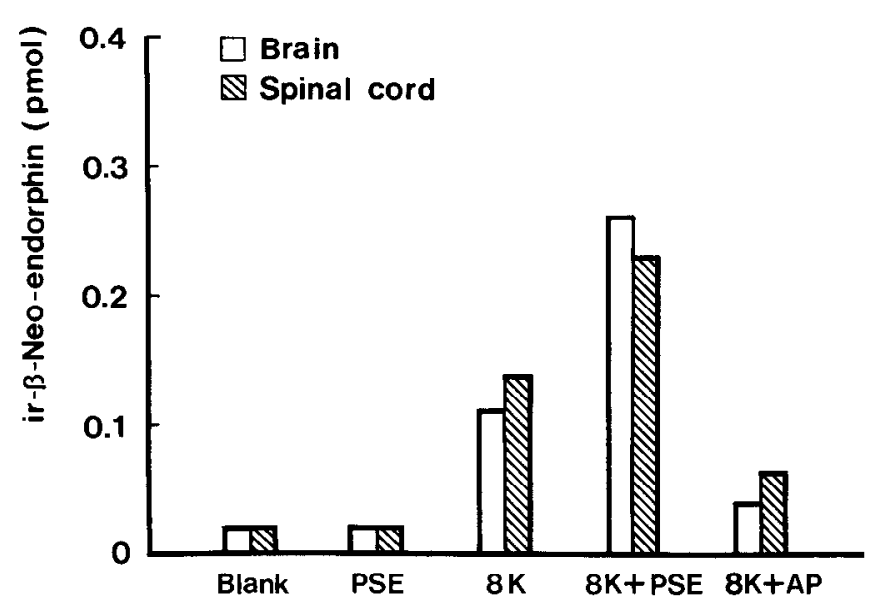

Figure 6. RIA of $8 \mathrm{kDa}$ Dyn by monoclonal antibody 3E7. Final dilution of antibody in this RIA was $5 \mu \mathrm{g} / 300 \mu \mathrm{l}$ tube. Blank, only RIA buffer; $A P$, aminopeptidase $\mathrm{M}(10 \mu \mathrm{g})$.

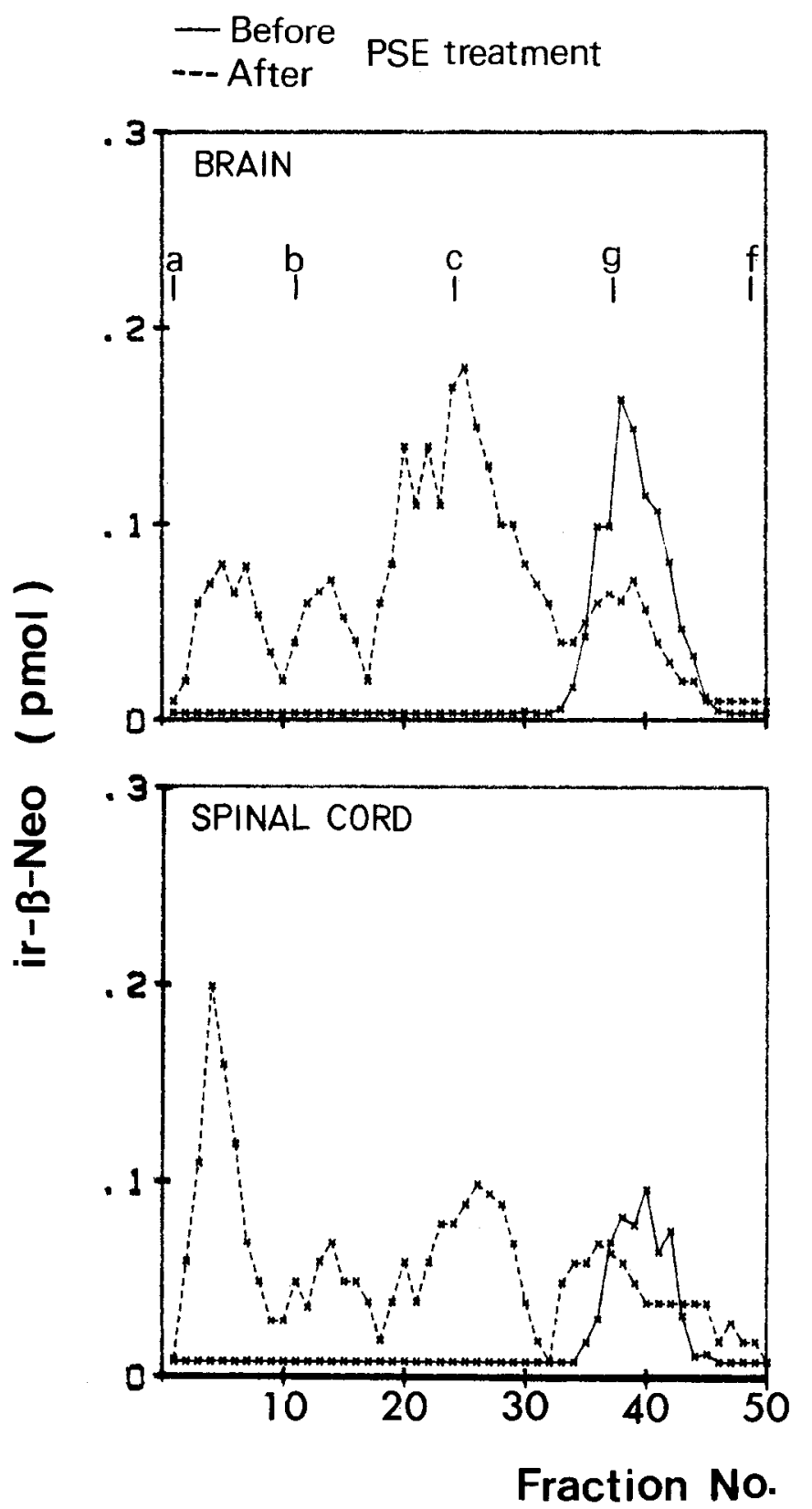

Figure 7. Sephadex G-50 patterns of ir- $\beta$-Neo from rat brain and spinal cord extracts before and after treatment of the fractions with PSE. Aliquots of each fraction were assayed directly by $\beta$-Neo antiserum (solid line) and after $2 \mathrm{hr}$ incubation with PSE (dashed line). Molecular-weight standards: $g,{ }^{125} \mathrm{I}-\beta-\mathrm{Neo}\left(\mathrm{M}_{r}=1224\right) ; a, b, c$, and $f$, as in Figure 2.

column than did Dyn A, Dyn B, or Dyn-32. Figure 5 shows the final HPLC purification of $8 \mathrm{kDa}$ Dyn from brain and spinal cord.

Amino terminus determination of $8 \mathrm{kDa}$ Dyn by monoclonal antibody

The results from the PSE hydrolysis experiment indicated that $8 \mathrm{kDa}$ Dyn contains Neo. But it was unclear if its amino-terminal residue was tyrosine- 1 of Neo. As the amount of purified $8 \mathrm{kDa}$ Dyn was too small for the dansyl method, $\beta$-Neo RIA, using monoclonal antibody $3 E 7$ specific to the amino-terminal sequence Tyr-Gly-Gly-Phe, was employed. As shown in Figure 6 , intact $8 \mathrm{kDa}$ Dyn from both brain and spinal cord was rec- 
ognized by $3 \mathrm{E} 7$. The immunoreactivity doubled after hydrolysis by PSE and was destroyed after incubation with $10 \mu \mathrm{g}$ aminopeptidase $M$. This result strongly suggests that the amino-terminal residue of $8 \mathrm{kDa}$ Dyn is tyrosine- 1 of $\beta-\mathrm{Neo}$.

\section{Large Dyn precursor in rat brain and spinal cord}

Sephadex G-50 chromatography of rat brain and spinal cord tissue extracts showed that, without any special treatment, only one peak of ir- $\beta$-Neo $\left(\mathrm{M}_{r}<2 \mathrm{kDa}\right.$ ) was directly detectable (Fig. $2, B, D)$. In order to find a larger Neo-containing precursor, all fractions from Sephadex G-50 filtration were treated with PSE as described. Several new ir- $\beta$-Neo peaks were observed at fractions corresponding to $\mathrm{M}_{r}>20,8$, and $4 \mathrm{kDa}$, respectively (Fig. 7). The decrease of the original ir- $\beta$-Neo peak $\left(\mathrm{M}_{r}<2 \mathrm{kDa}\right)$ after PSE treatment reflects the degradation by PSE demonstrated earlier.

The fractions containing the first peak $\left(\mathrm{M}_{r}>20 \mathrm{kDa}\right)$ were pooled, lyophilized, and redissolved in $500 \mu \mathrm{l}$ of $0.15 \mathrm{M}$ phosphate buffer ( $\mathrm{pH} 7.4$ ). The sample was applied to a calibrated gel filtration HPLC column (Bio-Sil TSK) and eluted with 0.15 M phosphate buffer. Fractions corresponding to $\mathrm{M}_{r}$ between 34 and $12 \mathrm{kDa}$ (as determined by pepsin and cytochrome c markers) were treated with PSE and subjected to both $\beta$-Neo and Dyn B (13S) RIA. Both immunoreactivities were found in the fractions with $\mathrm{M}$, about $26 \mathrm{kDa}$.

\section{Discussion}

We have confirmed previous reports (Cone et al., 1983; Seizinger et al., 1984) that there are 3 molecular-weight forms (6-8, 4 , and $2 \mathrm{kDa}$ ) of ir-Dyn $\mathrm{A}$ and $\mathrm{B}$ in rat and human brain (Gramsch et al., 1982). We have also shown here that a similar pattern exists in rat spinal cord, and that only small molecular forms $(<2 \mathrm{kDa})$ of ir-Dyn A-(1-8), $\alpha$-, and $\beta$-Neo are present in brain and spinal cord acetic acid extracts. Because the antisera for Dyn B, Dyn A-(1-8), or Neo used in this experiment are specific to the carboxyl terminus of the corresponding peptide, we conclude that all detectable forms of ir-Dyn B of different sizes (including the $8 \mathrm{kDa}$ form) terminate at carboxyl-terminal threonine-13 of Dyn B. Devi and Goldstein (1985) reported that in rat brain there is a single enzyme that converts Dyn B-29 (leumorphin) to Dyn B in a single step. According to the present study, this enzyme probably works at a very early stage of prodynorphin processing to remove the carboxyl-terminal extension of Dyn B in the precursor.

The $8 \mathrm{kDa}$ ir-Dyn present in rat brain and spinal cord was recognized by Dyn A antiserum (Lucia), Dyn B antiserum (13S, $17 \mathrm{~S}$ ), and also (after hydrolysis by PSE) by $\beta$-Neo antiserum, indicating that it contains all 3 opioid peptide regions. According to Civelli et al. (1985), there is a single gene encoding preprodynorphin in the rat. The recognition of $8 \mathrm{kDa}$ ir-Dyn by monoclonal antibody $3 E 7$ and by antiserum directed to the free carboxyl terminus of Dyn B indicates that the whole length of 8 $\mathrm{kDa}$ Dyn is from the amino-terminal tyrosine- 1 of Neo to the carboxyl-terminal threonine-13 of Dyn $\mathrm{B}$, comprising 68 residues (calculated $\mathrm{M}_{r}=8130$ ). This finding that $8 \mathrm{kDa}$ Dyn is composed of Neo, Dyn A, and Dyn B indicates that the cleavage of prodynorphin between its opioid and nonopioid parts occurs very early in processing. Whether the $8 \mathrm{kDa}$ Dyn is only an immediate precursor for bioactive dynorphins and neo-endorphins, or whether it is secreted itself as an active neurotransmitter or hormone is still unknown.

Different sizes of large dynorphins were reported in different neural tissues. The $7 \mathrm{kDa}$ Dyn from rat brain reported by Cone et al. (1983) is evidently the same material as the $8 \mathrm{kDa}$ Dyn described in this study. Cone et al. (1983) also found that irDyn A and ir-Dyn B were exclusively of the $7 \mathrm{kDa}$ species in rat anterior pituitary. Similar findings were reported by Seizinger et al. (1981, 1984) and Spampinato and Goldstein (1983). Gramsch et al. (1982) reported that, in human brain, ir-Dyn A was shown to consist of 4 peaks, with $M_{r}$ about 12,6, 1.8, and $1 \mathrm{kDa}$, and Christensson-Nylander et al. (1985) found that there were 3 peaks of $M_{r}$ about 5,2 , and $1 \mathrm{kDa}$ for ir-Dyn $\mathrm{A}$ and 3 peaks with $\mathrm{M}_{r}$ about 10,5 , and $1.5 \mathrm{kDa}$ for ir-Dyn $\mathrm{B}$ in human hypothalamus. Similar patterns were revealed in human substantia nigra (Christensson-Nylander and Terenius, 1985). We cannot compare those substances with the $8 \mathrm{kDa}$ Dyn because the authors did not describe the structures in detail. Recently, Day and Akil (1986) reported a $16 \mathrm{kDa}$ species containing $\alpha$-Neo in its carboxyl terminus and an $8.5 \mathrm{kDa}$ ir-Dyn containing Dyn A, Dyn B, and bridge peptide, but not Neo in rat adenohypophysis. These results suggest different processing patterns in different tissues.

All opioid peptides in prodynorphin are carboxyl-terminally extended [Leu]enkephalins containing basic residues. Therefore, the treatment with trypsin and carboxypeptidase B for releasing internal enkephalin sequences prior to RIA, used to analyze the enkephalin precursor (Udenfriend and Kilpatrick, 1984), cannot be employed to distinguish the several neo-endorphins and dynorphins. In the present study, therefore, we used a novel procedure-treatment with PSE to release the carboxyl terminus of $\beta$-Neo from a large precursor, and we measured the ir- $\beta$-Neo by RIA with a specific antiserum directed to its carboxyl terminus. Using this method, we were able to find a $4 \mathrm{kDa}$ ir $-\beta$ Neo peak that was not detectable prior to PSE treatment (Fig. 7). This indicates that the $8 \mathrm{kDa}$ peptide could generate not only the well-known 4 kDa Dyn-32 (containing Dyn A and Dyn B), but also a $4 \mathrm{kDa} \mathrm{NH}_{2}$-terminal fragment containing Neo and bridge peptide.

In the sequence of prodynorphin, there is only one copy of $\beta$-Neo, so we can now estimate the molar amount of Dyn precursor molecules in the tissue by means of PSE hydrolysis. In the spinal cord, only $0.41+0.02 \mathrm{pmol} / \mathrm{gm}$ Dyn A equivalent of $8 \mathrm{kDa}$ precursor was detected directly by Lucia, but $4.2 \mathrm{pmol}$ of ir- $\beta$-Neo was generated after PSE treatment in the presence of enzyme inhibitor. Thus, the internally directed antibody Lucia, which recognizes Dyn A-(3-12), has only $10 \%$ cross-reactivity with $8 \mathrm{kDa}$ Dyn. In the same way, we find that the Dyn $B$ antisera (13S and 17S) have $13 \%$ cross-reactivity with $8 \mathrm{kDa}$ Dyn. Because of the low cross-reactivity, none of the antisera used in this study could recognize the big precursor $(26 \mathrm{kDa})$. However, by measuring the molar amount of ir- $\beta$-Neo generated from the precursor after PSE treatment, we find about $1.0 \mathrm{pmol} /$ gm of $26 \mathrm{kDa}$ precursor present in brain and about $1.6 \mathrm{pmol} /$ $\mathrm{gm}$ in spinal cord. This large dynorphin corresponds, in molecular weight, to the entire dynorphin gene product (Kakidani et al., 1982).

\section{References}

Christensson-Nylander, I., and L. Terenius (1985) Dynorphin peptides in human substantia nigra. Neuropeptides 6: 391-396.

Christensson-Nylander, I., F. Nyberg, U. Ragnarsson, and L. Terenius (1985) A general procedure for analysis of proenkephalin B derived opioid peptides. Reg. Pept. 11: 65-76.

Civelli, O., J. Douglass, and E. Herbert (1984) Pro-opiomelanocortin: A polyprotein at the interface of the endocrine and nervous systems. 
In The Peptides, Vol. 6, S. Udenfriend and J. Meienhofer, eds., pp. 69-94, Academic, New York.

Civelli, O., J. Douglass, A. Goldstein, and E. Herbert (1985) Sequence and expression of the rat prodynorphin gene. Proc. Natl. Acad. Sci. USA 82: 4291-4295.

Cone, R. I., and A. Goldstein (1982) A specific radioimmunoassay for the opioid peptide dynorphin B in neural tissues. Neuropeptides 3: 97-106.

Cone, R. I. F. Weber J. D. Barchas and A. Goldstein (1983) Regional distribution of dynorphin and neo-endorphin peptides in rat brain, spinal cord, and pituitary. J. Neurosci. 3: 2146-2152.

Day, R., and H. Akil (1986) Processing of prodynorphin in the rat adenohypophysis. In Proceedings of the International Narcotic Research Conference, San Francisco, July 1986, p. 49 (Abstr.).

Devi, L., and A. Goldstein (1984) Dynorphin converting enzyme with unusual specificity from rat brain. Proc. Natl. Acad. Sci. USA 81: 1892-1896.

Devi, L., and A. Goldstein (1985) Neuropeptide processing by singlestep cleavage: Conversion of leumorphin (dynorphin B-29) to dynorphin B. Biochem. Biophys. Res. Commun. 130: 1168-1176.

Fischli, W., A. Goldstein, M. Hunkapiller, and L. Hood (1982) Isolation and amino acid sequence analysis of a 4,000-dalton dynorphin from porcine pituitary. Proc. Natl. Acad. Sci. USA 79: 5435-5437.

Ghazarossian, V. E., C. Chavkin, and A. Goldstein (1980) A specific radioimmunoassay for the novel opioid peptide dynorphin. Life Sci. 27: 75-86.

Goldstein, A., S. Tachibana, L. I. Lowney, M. Hunkapiller, and L. Hood (1979) Dynorphin-(1-13), an extraordinarily potent opioid peptide. Proc. Natl. Acad. Sci. USA 76: 6666-6670.

Gramsch, G., V. Hollt, A. Pasi, P. Mehraein, and A. Herz (1982) Immunoreactive dynorphin in human brain and pituitary. Brain Res. 233: 65-74.

Horikawa, S., T. Takai, M. Toyosato, H. Takahashi, M. Noda, H. Kakadani, T. Kubo, T. Hirose, S. Inayama, H. Hayashida, T. Miyata, and S. Numa (1983) Isolation and structural organization of the human preproenkephalin B gene. Nature 306: 611-614.

Kakidani. H.. Y. Furutani, H. Takahashi, M. Noda, Y. Morimoto, T. Hirose, M. Asai, S. Inayama, S. Nakanishi, and S. Numa (1982) Cloning and sequence analysis of cDNA for porcine $\beta$-neo-endorphin/ dynorphin precursor. Nature 298: 245-249.

Kangawa, K., N. Minamino, N. Chino, S. Sakakibara, and H. Matsuo (1981) The complete amino acid sequence of $\alpha$-neo-endorphin. Biochem. Biophys. Res. Commun. 99: 871-878.
Kilpatrick, D. L. A Wahlstrom, H. W. Lahm, R. Blacher, and S. Udenfriend (1982) Rimorphin, a unique, naturally occurring [Leu]enkephalin-containing peptide found in association with dynorphin and $\alpha$-neo-endorphin. Proc. Natl. Acad. Sci. USA 79:64806483

Meo, T., C. Gramsch, R. Inan, V. Hollt, E. Weber, A. Herz, and G. Riethmuller (1983) Monoclonal antibody to the message sequence Tyr-Gly-Gly-Phe of opioid peptides exhibits the specificity requirements of mammalian opioid receptors Proc. Natl. Acad. Sci. USA 80: 4084-4088.

Minamino, N., K. Kangawa, A. Fukuda, and H. Matsuo (1980) A new opioid octapeptide related to dynorphin from porcine hypothalamus. Biochem. Biophys. Res. Commun. 95: 1475-1481.

Minamino, N., K. Kangawa, N. Chino, S. Sakakibara, and H. Matsuo (1981) $\beta$-Neo-endorphin, a new hypothalamic "big" leu-enkephalin of porcine origin: Its purification and the complete amino acid sequence. Biochem. Biophys. Res. Commun. 99: 864-870.

Nakao, K., M. Suda, M. Sakamoto, T. Yoshimasa, N. Morii, Y. Ikeda, C. Yanaihara, N. Yanaihara, S. Numa, and H. Imura (1983) Leumorphin is a novel endogenous opioid peptide derived from preproenkephalin B. Biochem. Biophys. Res. Commun. 117: 695-701.

Seizinger, B. R., V. Hollt, and A. Herz (1981) Immunoreactive dynorphin in the rat adenohypophysis consists exclusively of $6000 \mathrm{dal}-$ ton species. Biochem. Biophys. Res. Comun. 103: 256-263.

Seizinger, B. R., C. Grimm, V. Hollt, and A. Herz (1984) Evidence for a selective processing of proenkephalin B into different opioid peptide forms in particular regions of rat brain and pituitary. J. Neurochem. 42: 447-457.

Spampinato, S., and A. Goldstein (1983) Immunoreactive dynurphir in rat tissues and plasma. Neuropeptides 3: 193-212.

Udenfriend, S., and D. L. Kilpatrick (1984) Proenkephalin and the products of its processing: Chemistry and biology. In the Peptides, Vol. 6, S. Udenfriend and J. Meienhofer, eds., pp. 25-68, Academic, New York.

Weber, E., C. J. Evans, and J. D. Barchas (1982a) Predominance of the amino-terminal octapeptide fragment of dynorphin in rat brain regions. Nature 299: 77-79.

Weber, E., C. J. Evans, J. K. Chang, and J. D. Barchas (1982b) Brain distribution of $\alpha$-neo-endorphin and $\beta$-neo-endorphin; Evidence for regional processing differences. Biochem. Biophys. Res. Commun. 108: $81-88$

Yoshimoto, T., R. Walter, and D. Tsuru (1980) Proline-specific endopeptidase from Flavobacteriurr. J. Biol. Chem. 255: 4786-4792. 